Article

\title{
Geodynamic Significance of the Mesoproterozoic Magmatism of the Udzha Paleo-Rift (Northern Siberian Craton) Based on U-Pb Geochronology and Paleomagnetic Data
}

\author{
Sergey V. Malyshev ${ }^{1, *(\mathbb{C}}$, Aleksander M. Pasenko ${ }^{2}$, Alexei V. Ivanov ${ }^{3}$, Dmitrii P. Gladkochub ${ }^{3,4}$, \\ Valery M. Savatenkov ${ }^{1,5}$, Sebastien Meffre ${ }^{6}$, Adam Abersteiner ${ }^{6}$, Vadim S. Kamenetsky ${ }^{6}$ (D) \\ and Vasiliy. D. Shcherbakov ${ }^{7}$ \\ 1 Institute of Earth Sciences, St. Petersburg State University, 7/9 University Nab., \\ 199034 St. Petersburg, Russia; v.m.savatenkov@ipgg.ru \\ 2 Schmidt Institute of Physics of the Earth, Russian Academy of Sciences, Bolshaya Gruzinskaya St., \\ 123242 10-1 Moscow, Russia; pasenkoal@ya.ru \\ 3 Institute of the Earth's Crust, Siberian Branch of the Russian Academy of Sciences, Lermontova St. 128, \\ 664033 Irkutsk, Russia; aivanov@crust.irk.ru (A.V.I.); dima@crust.irk.ru (D.P.G.) \\ 4 Geological Department, Irkutsk State University, Karl Marks St. 1, 664003 Irkutsk, Russia \\ 5 Institute of Precambrian Geology and Geochronology, Russian Academy of Sciences, Makarova Nab. 2, \\ 199034 St. Petersburg, Russia \\ 6 School of Natural Sciences, University of Tasmania, Churchill Ave, Hobart TAS 7005, Australia; \\ Sebastien.Meffre@utas.edu.au (S.M.); adam.abersteiner@utas.edu.au (A.A.); \\ Dima.Kamenetsky@utas.edu.au (V.S.K.) \\ 7 Faculty of Geology, Lomonosov Moscow State University, Leninskiye Gory GSP-1.1, 119991 Moscow, Russia; \\ vasiliy7@gmail.com \\ * Correspondence: s.malyshev@spbu.ru; Tel.: +7-921-779-3550
}

Received: 9 November 2018; Accepted: 23 November 2018; Published: 29 November 2018

check for updates

\begin{abstract}
The emplacement age of the Great Udzha Dyke (northern Siberian Craton) was determined by the U-Pb dating of apatite using laser ablation inductively coupled plasma mass spectrometry (LA-ICPMS). This produced an age of $1386 \pm 30 \mathrm{Ma}$. This dyke along with two other adjacent intrusions, which cross-cut the sedimentary units of the Udzha paleo-rift, were subjected to paleomagnetic investigation. The paleomagnetic poles for the Udzha paleo-rift intrusions are consistent with previous results published for the Chieress dyke in the Anabar shield of the Siberian Craton (1384 $\pm 2 \mathrm{Ma})$. Our results suggest that there was a period of intense volcanism in the northern Siberian Craton, as well as allow us to reconstruct the apparent migration of the Siberian Craton during the Mesoproterozoic.
\end{abstract}

Keywords: U-Pb geochronology; apatite; basalts; proterozoic; Siberia; paleomagnetism; paleoreconstruction

\section{Introduction}

The Udzha structure is located between the Anabar shield and Olenek uplift in the northern part of the Siberian Craton (Russia) and is orientated along a north-south trending paleo-rift [1] (Figure 1). Inside the Udzha paleo-rift, Meso- and Neoproterozoic volcano-sedimentary rocks are exposed, which are cross-cut by mafic intrusions. Precambrian successions are covered by Phanerozoic sediments along an unconformity. The pre-Late Neoproterozoic sequence is divided into two units: (i) Limey-shales with tuff interbeds of the Ulahan-Kurung and Ungoakhtah formation, (ii) carbonate-dominated Khapchanyr formation and terrigenous Udzha formation, which has an 
overall thickness of $\sim 1500 \mathrm{~m}$. The depositional age of this part of the succession was estimated to range from $1320 \mathrm{Ma}$ to $820 \mathrm{Ma}$, based on the K-Ar dating of the intrusions and sedimentary glauconite, and regional correlations of stromatolites. Therefore, the Udzha basin is considered to be a long-lived basin, which evolved over a period of at least $500 \mathrm{Ma}$. Gladkochub et al. [1] disputed this age after obtaining a new Ar-Ar age of $1074 \pm 11$ Ma for magmatic plagioclase from a mafic dyke, which cross-cuts the Ungoakhtah formation. Based on this age, Gladkochub et al. [1] constrained a Mesoproterozoic age for the mafic magmatic complex of the Udzha paleo-rift [1]. Furthermore, some of the adjacent dykes of the Udzha magmatic complex cross-cut the Udzha formation, which was used by Gladkochub et al. [1] to constrain a minimum age of $1074 \pm 11 \mathrm{Ma}$ of sedimentation. However, we do not consider this age to be a conclusive estimate for this intrusion, as the Ar-Ar age spectra did not yield a statistically acceptable plateau. In this study, we apply the $\mathrm{U}-\mathrm{Pb}$ method to date the Great Udzha Dyke. This dyke cross-cuts the pre-Neoproterozoic sedimentary successions, which can provide new constraints on the minimum age of sedimentation in the Udzha paleo-rift. In addition, we employed paleomagnetic analyses in order to correlate this dyke with the other dykes from the Udzha paleo-rift and discuss the possible, apparent migration of the Siberian Craton during the Mesoproterozoic.
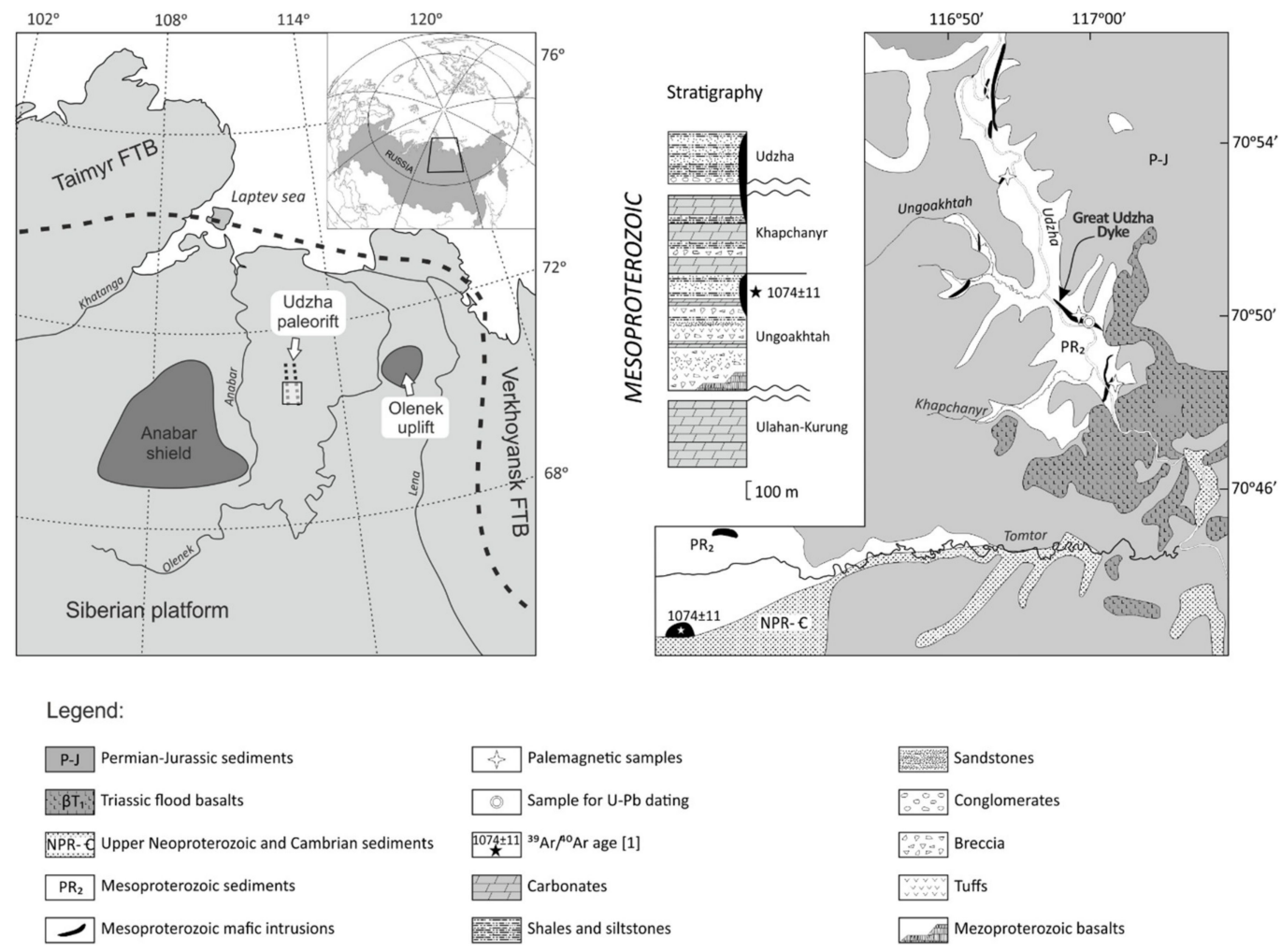

Figure 1. Location of the Udzha paleo-rift in the northern Siberian Craton (left), and the distribution of the Mesoproterozoic dykes within the geological framework and the location of studied samples (right). The bold dotted curve outlines the boundary of the Siberian Craton.

\section{Samples and Methodology}

The regionally largest dyke-the Great Udzha Dyke (GUD), located on the eastern bank of the Udzha River $\left(70^{\circ} 49^{\prime} 50.70^{\prime \prime} \mathrm{N}, 117^{\circ} 0^{\prime} 7.50^{\prime \prime} \mathrm{E}\right)$, was selected for U-Pb dating. The GUD has a northwest-southeast trending strike, is roughly $200 \mathrm{~m}$ in thickness and cross-cuts the Khapchanyr and Udzha sedimentary formations. The dyke is a medium-grained dolerite with ophitic and coarse grain textures and is composed of plagioclase (60-65 vol. \%), clinopyroxene (20-25 vol. \%), quartz ( 10 vol. \%) and hornblende (5 vol. \%). Secondary minerals, such as saussurite, sericite and 
chlorite are common, due to low temperature alteration. The chemical composition of these rocks corresponds to moderately alkaline basalts $\left(\mathrm{SiO}_{2}=46-52 \% ; \mathrm{K}_{2} \mathrm{O}+\mathrm{Na}_{2} \mathrm{O}=1.7-4.4 \%\right)$.

Samples were collected from the coarsest grain central part of the dyke and heavy mineral fractions were extracted, which contain transparent green-yellow apatite without apparent signs of secondary alteration or recrystallization. No zircon or baddeleyite were found. Therefore apatite was employed for $\mathrm{U}-\mathrm{Pb}$ dating, which was performed at the University of Tasmania (Hobart, Australia) by laser ablation inductively coupled plasma mass spectrometry (LA-ICPMS) using an Agilent 7900 quadrupole mass-spectrometer connected to a $193 \mathrm{~nm}$ Coherent Ar-F excimer laser and Resonetics S155 ablation cell $[2,3]$. Details of the procedure are provided in the Supplementary File along with the full analytical dataset.

Paleomagnetic studies were carried out to correlate the GUD with other intrusive bodies. In addition to the GUD we sampled a sill, which is located within the Udzha formation near the junction of the Hapchanyr and Udzha rivers $\left(70^{\circ} 48^{\prime} 43.80^{\prime \prime} \mathrm{N}, 117^{\circ} 2^{\prime} 0.78^{\prime \prime} \mathrm{E}\right)$ and a dyke located 2.4 $\mathrm{km}$ to the north along the Udzha River from the mouth of the Ungoakhtah River $\left(70^{\circ} 53^{\prime} 07.8^{\prime \prime} \mathrm{N}\right.$, $116^{\circ} 53^{\prime} 56.4^{\prime \prime} \mathrm{E}$ ). For each intrusive body we collected $7-15$ oriented blocks, which were later prepared as oriented $\sim 8 \mathrm{~cm}^{3}$ cubic samples for analyses. Samples for paleomagnetic measurements have been taken from various parts of intrusive bodies, including both the endocontact zones of the intrusions and central parts. Well-exposed endocontact zones were prioritized. Samples were oriented using a magnetic compass with controls employed to mitigate possible deflection of the compass needle caused by the strongly magnetized rocks. Samples were then cut using a water-cooled rock saw to prevent the heating of the samples.

To isolate the components of magnetization, the samples were subjected to stepwise temperature demagnetization in the Laboratory of the Main Geomagnetic Field and Petromagnetism at the Institute of the Physics of the Earth (Moscow, Russia). All samples were thermally demagnetized between $560-580{ }^{\circ} \mathrm{C}$ with an average of 12 to 15 steps to isolate the components of natural remnant magnetization (NRM). The paleomagnetic directions were determined from the principal component analysis [4]. Site mean directions based on 4 to 14 samples results were calculated using Fisher statistics [5]. The paleomagnetic measurements were conducted using a 2G-Enterprise cryogenic magnetometer and a JR-6 spinner magnetometer (AGICO). Heating was performed in a MMTD-80 (Magnetic Measurements Ltd., Aughton, UK) thermal demagnetizer.

In order to identify magnetic minerals, measurements of coercivity and thermomagnetic properties were carried out. Hysteretic parameters were obtained by a PMC MicroMag 3900 VSM vibromagnetometer (Lake Shore Cryotronics, Westerville, OH, USA) in a maximum field of $1.6 \mathrm{~T}$ and then corrected for paramagnetic/diamagnetic substance contribution. Temperature dependences of magnetic susceptibility were measured using an MFK-1A kappabridge (AGICO, Brno, Czech Republic). The measurement of saturation magnetization versus temperature was carried out in the field $\sim 800 \mathrm{mT}$ with a vibrating sample magnetometer designed by $Y$. Vinogradov.

Electron microscope analyses were used to determine the structure and composition of magnetic minerals. Back scattered electrons (BSE) images were acquired at accelerating voltage $20 \mathrm{kV}$ and beam current $10 \mathrm{nA}$ using Jeol JSM-6480 electron microscope (Faculty of Geology, MSU, Moscow, Russia). Phase identification was conducted by energy-dispersive spectrometry (EDS) analyses.

The directional data were processed by the least squares method [4] using the Enkin package [6]. Reconstructions were made using the GMAP-2003 freeware package [7]. The local magnetic declination was calculated using the IGRF-12 model (British Geological Survey, Nottingham, UK).

\section{U-Pb Dating Results}

A typical apatite grain used for the U-Pb dating is shown in Figure 2. It hosts primary melt inclusions, which support a magmatic origin. The apatite grain was large enough to employ $30 \mu \mathrm{m}$ diameter laser ablation spots to grain regions free of mineral and melt inclusions. 


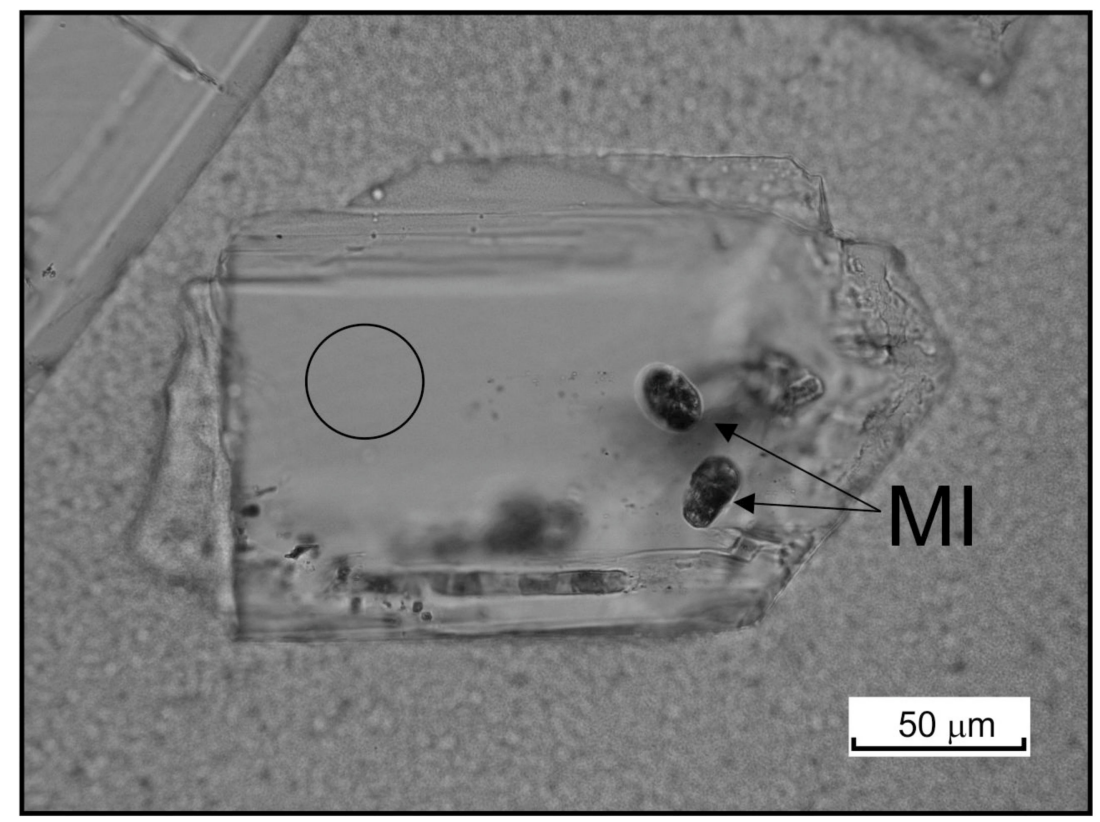

Figure 2. A typical apatite grain used for the U-Pb dating. MI-melt inclusions. The circle shows the size of the laser ablation spot.

On the Tera-Wasserburg diagram, the analyzed apatite grains are discordant, but form a pronounced regression line. At zero ${ }^{238} \mathrm{U} /{ }^{206} \mathrm{~Pb}$, this regression line is anchored using the isotope composition of lead obtained from calcite from the same dyke, and in the lower part of the concordia, the regression line intercepts it at $1386 \pm 30 \mathrm{Ma}$ (Figure 3).

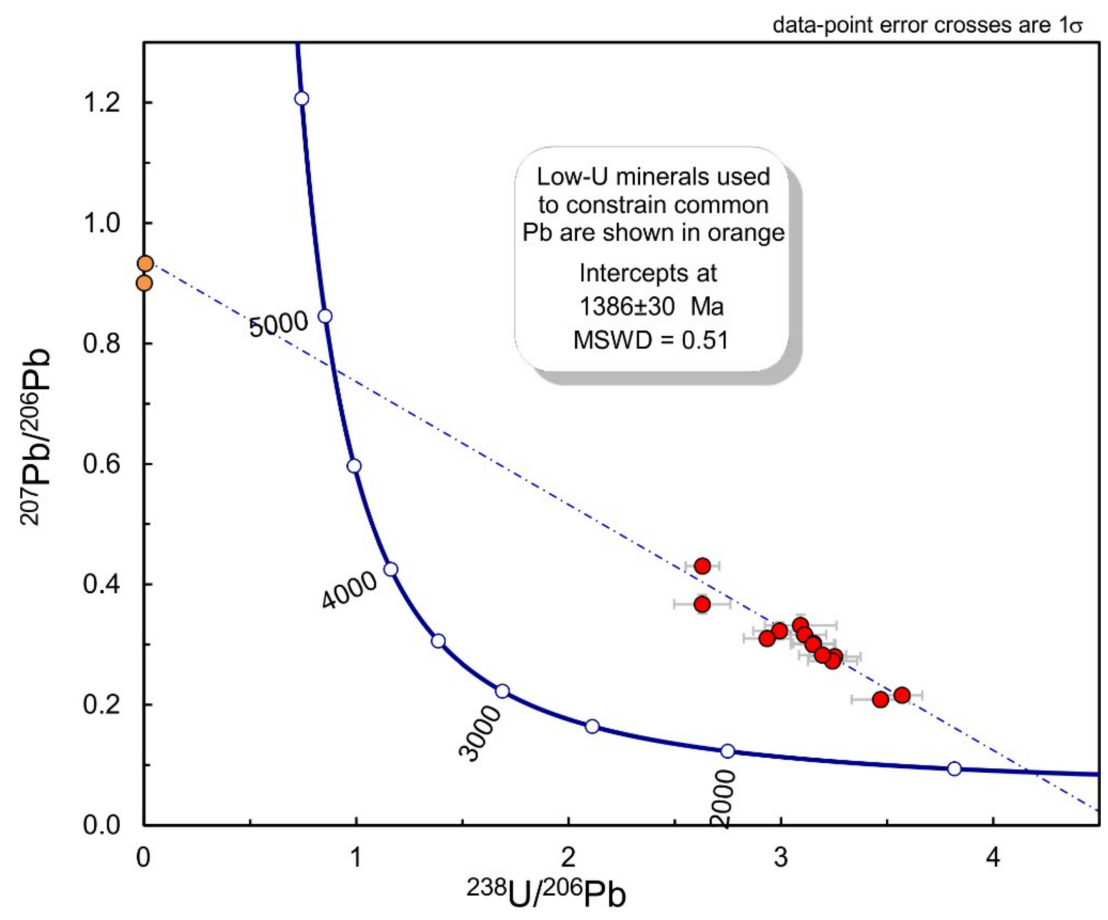

Figure 3. Tera-Wasserburg concordia diagram for the dated apatite grains.

\section{Paleomagnetic Results}

The paleomagnetic and rock-magnetic properties of samples collected from the studied magmatic bodies are quite similar. The thermal demagnetization of the natural remnant magnetization 
(NRM) of most studied samples revealed (Figure 4) the presence of two magnetization components: Low and high temperature ones (LT and HT). Several samples also contain a middle temperature (MT) component, which is destroyed between $350-500{ }^{\circ} \mathrm{C}$. The projections of this component form a quasi-random distribution on a stereogram, which makes it impractical for any meaningful interpretation. Regardless of the origin of this component (e.g., lightning, transformation of minerals during oxidation, etc.), it seems unlikely that it carries any useful information for purposes of the present study. Therefore, we will not consider this component further.

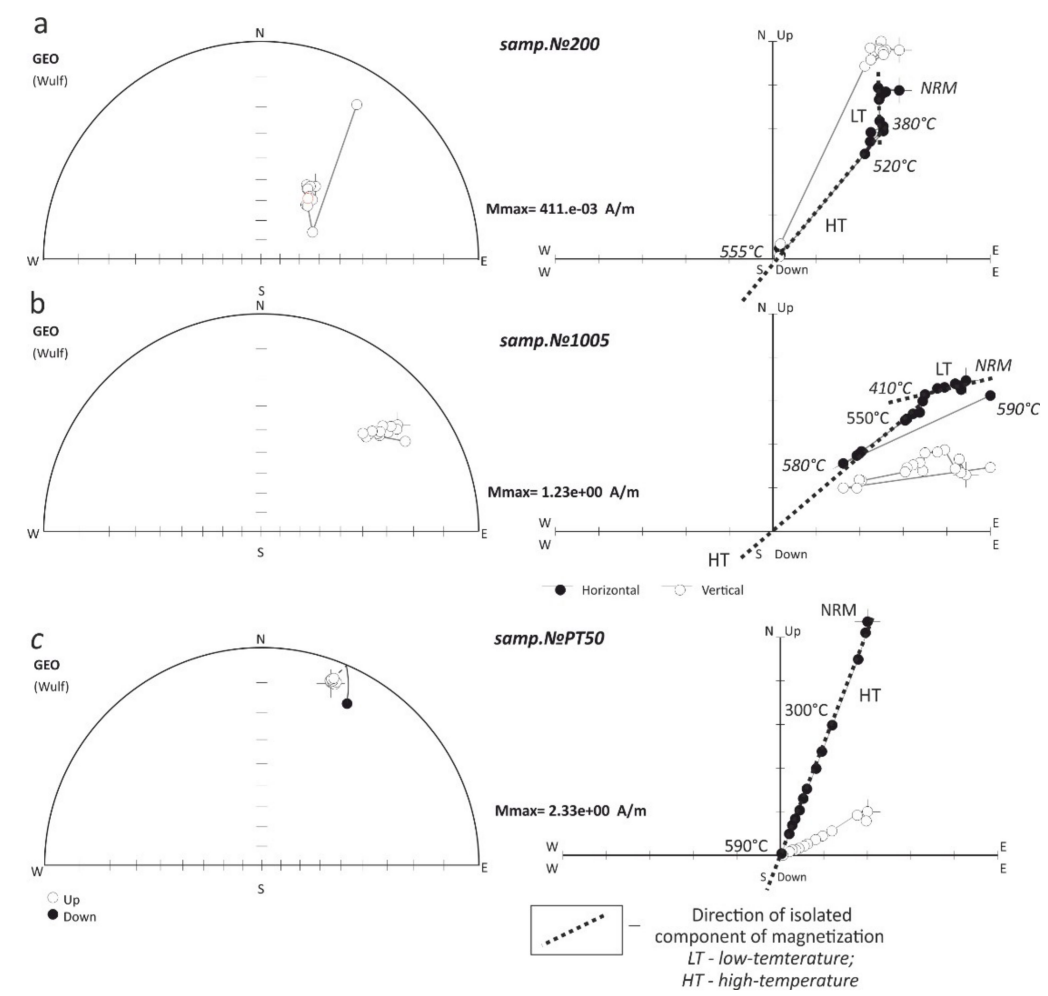

Figure 4. Representative orthogonal demagnetization diagrams and equal-area stereonet plots of mafic bodies of the Udzha Uplift. (a) Sample No. 200—the Great Udzha Dyke (1); (b) sample No. 1005—sill at the Udzha and Hapchanyr river junction (2); (c) sample No. PT50—dyke (3).

The direction of the LT component was isolated between $120-150{ }^{\circ} \mathrm{C}$ and is scattered around the direction of the modern geomagnetic field. Therefore, we consider it as a mixture of a laboratory viscous component and a component of recent origin (viscous or chemical) acquired in situ (Figure 5, Table 1).

The most stable HT component is isolated between $550-580{ }^{\circ} \mathrm{C}$ (Figure 4). These unblocking temperatures indicate that magnetite and/or low-titanium titanomagnetite dominate the magnetic mineralogy in the studied samples. This conclusion is further supported by the results of the coercivity and thermomagnetic measurements.

Mean directions of HT components isolated for studied magmatic bodies are presented in Table 1. They all have moderate to shallow negative inclinations and north-north-eastern declinations. We note that the success rate is diverse for different magmatic bodies. Virtually all samples from the sill at the Udzha and Hapchanyr rivers junction contain HT components, and only a few samples from the studied dyke show a clear paleomagnetic record (see Table 1).

For studied samples, the hysteresis loop closes below $0.3 \mathrm{~T}$ (Figure 6). This points towards the low coercivity of the magnetic minerals (i.e., carriers of the magnetization). Hysteretic parameters summarized on the Day-Dunlop plot (Figure 7) [8-10] show that our samples contain pseudo-single-domain (PSD) magnetic particles. The latter is also evidenced from the observed Hopkinson peak on the temperature dependence on the magnetic susceptibility (Figure 6). 
Note that PSD grains are usually considered to be stable magnetic carriers over large geological timescales [11]. Thermomagnetic analyses indicate that the main magnetic carrier in the studied rock is the mineral with the Curie point around $\sim 570{ }^{\circ} \mathrm{C}$ (Figure 6). Thus, all obtained rock-magnetic data, including the maximum values of the unblocking temperatures, thermomagnetic and coercivity properties indicate that the HT component in the studied samples is hosted in PSD magnetite or low titanium titanomagnetite [11,12].

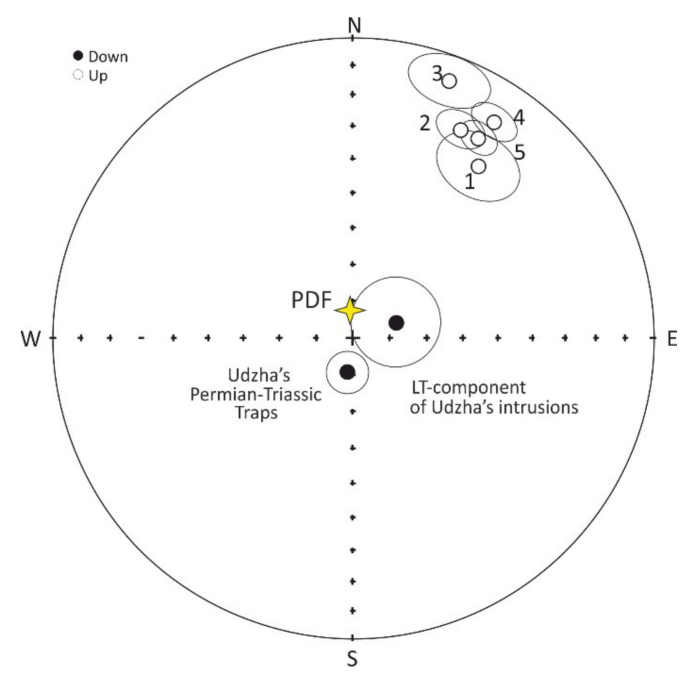

Figure 5. Equal-area stereographic projection of all site means reported in this study. 1-the Great Udzha Dyke; 2-sill at the Udzha and Hapchanyr river junction; 3-dyke; 4-dykes of the Kotuy-Olenek complex [14]; 5-sill at the Udzha and Hapchanyr river junction [14]. PDF-present day magnetic field in the study area.
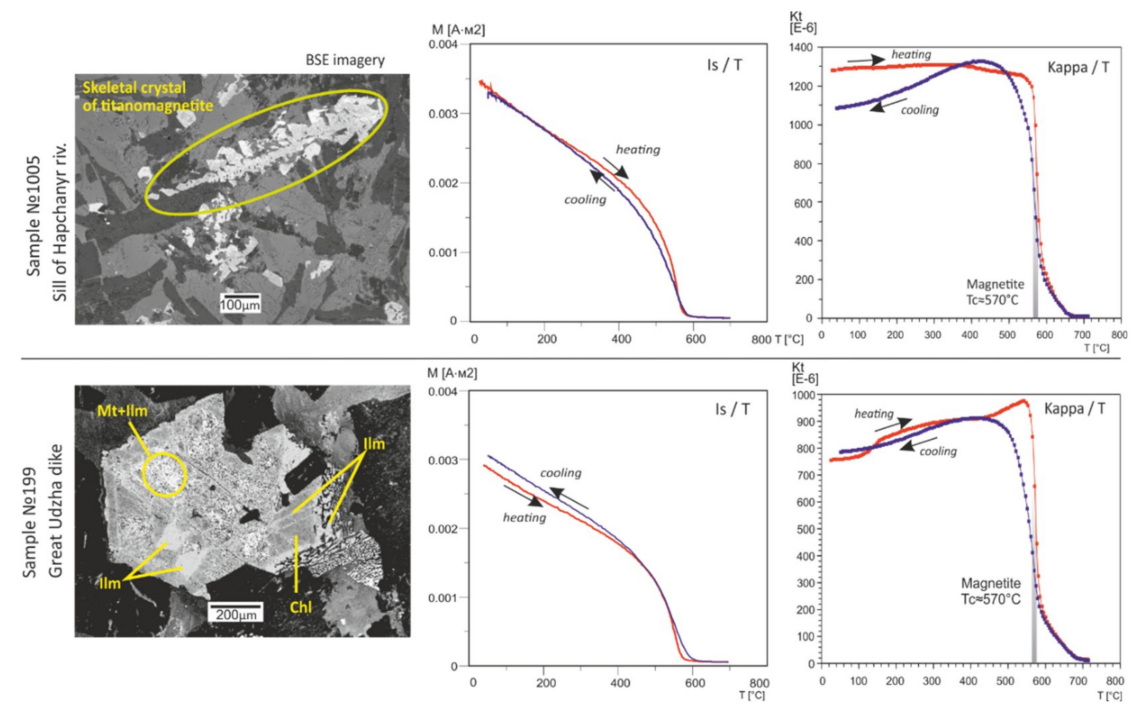

Figure 6. Data of microprobe analysis (BSE imagery), the relation of the saturation magnetization from temperature and susceptibility versus the temperature for heating and cooling for rocks of the Great Udzha Dyke and the sill at the Udzha and Hapchanyr river junction. Abbreviation for SEM imagery: Mt—magnetite; Ilm-ilmenite; Chl—chlorite. 


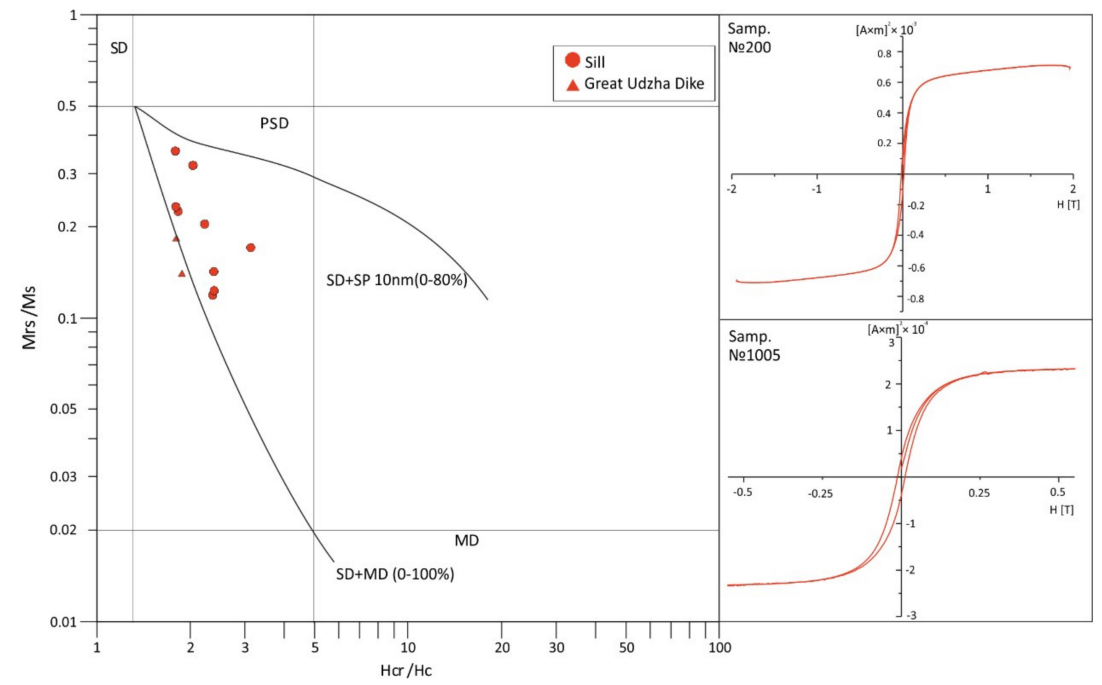

Figure 7. Plot of hysteresis parameters and hysteresis loops samples from the Great Udzha Dyke and the sill at the Udzha and Haphanyr river junction (Mrs/Ms = ratio of saturation remanence to saturation magnetization; $\mathrm{Hcr} / \mathrm{Hc}=$ ratio of coercivity of remanence to coercivity) from samples plotted against the canonical fields [8-10] of single-domain (SD), pseudo-single-domain (PSD) and multi-domain (MD) magnetite. In the diagram, the values of the hysteresis parameters are located in the field of pseudo-single-domain grains. Right-characteristic hysteresis loops of the GUD (No. 200) and sill (No. 1005) samples are shown.

The examination of polished sections show the occurrence of the titanomagnetite grains with magnetite/ilmenite intergrowths (exsolution lamellae) or with dendritic-skeletal structures (Figure 6). The former feature is a clear indication of the high-temperature oxidation of primary titanomagnetite grains. This forms deuterically during the rapid cooling of the intruded rocks between $900{ }^{\circ} \mathrm{C}$ to $500{ }^{\circ} \mathrm{C}$ [13]. This is strong evidence for the very quick formation of the grains during cooling and their primary origin.

The mean directions of the HT components of magnetization isolated in the studied magmatic bodies, as well as the directions of the HT components of the magnetization, determined by Konstantinov [14] in numerous other intrusions of the Udzha River Valley are listed in Table 1 (Figure 7). However, the results of Konstantinov [14] are only presented in the abstract as finite directions without a detailed description of the results. Consequently, this does not allow us to consider this data for the calculation of the paleomagnetic pole. However, it is noteworthy that the proximity of these directions with ours indicates that the intrusive bodies in this study are possibly of the same age.

The available geological samples limit the ability to apply field tests to constrain the timing of formation of the isolated HT-component. Nevertheless, several lines of evidence can be cited to support its primary origin. This includes:

1. Statistically significant differences $\left(\gamma / \gamma_{\mathrm{cr}}=29.62^{\circ} / 30.52^{\circ}\right)$ between the mean direction of the HT component and the mean paleomagnetic direction obtained from the unbaked host rocks of the Udzha formation (Table 1, Figure 7) $[15,16]$. Unfortunately, baked contacts themselves are not exposed, and therefore we must treat this result only as a conditional positive contact test. Nevertheless, the obtained data clearly support the absence of large regional remagnetization events after the accumulation of rocks of the Udzha formation, and the emplacement of the studied intrusions.

2. With the exception of Siberian traps, which are widespread in the lower course of the Udzha River, there are no traces of any magmatic events in the studied region that could lead to the remagnetization of the studied rocks. In the paleomagnetic recording of the studied rocks, there are no any indications of remagnetization by Permian-Triassic traps. The directions of 
all the selected components are noticeably different from the average paleomagnetic direction obtained earlier from the Udzha traps [17]. Thus, the probability of the remagnetization of the studied rocks by the Siberian traps can be excluded. The influence of a partial remagnetization of the present magnetic field (LT component) is easily removed by heating to $120^{\circ} \mathrm{C}$. The character of the distribution of MT vectors, as noted above, does not allow the association of it with some general remagnetization event, moreover, this component is also easily removed during the demagnetization. Thus, the formation of HT components in the studied magmatic bodies and in the host rocks due to the subsequent remagnetization events is very unlikely.

3. The virtual geomagnetic pole (VGP) calculated from the HT component (Table 2) is located at a considerable distance from any known Neoproterozoic and Phanerozoic poles in the Siberian platform (e.g., References [18,19]) (Figure 8). This observation advocates the early formation of the HT component, however, the Siberian Meso-Neoproterozoic apparent polar wander path (APWP) is poorly established, and therefore cannot be considered as a decisive argument. Nevertheless, this presents substantial support for our assertion.

4. The resulting pole matches well with a small number of currently known Mesoproterozoic poles of the Siberian platform. It is positioned between the reliable paleomagnetic poles of Siberia for $1500 \mathrm{Ma}$ and $1045 \mathrm{Ma}$ (Figure 8; [15,18-27]) and is concordant with the hypothesis for the primary origin of the HT component.

5. Electron microscope data indicate that grains of magnetic minerals were formed during the emplacement and cooling of the studied intrusions.

6. Data from rock magnetic studies confirm that magnetization is carried by PSD grains, which can retain the primary magnetization for large geological time scales.

Studies by Konstantinov [14] of Precambrian intrusions exposed in the valley of the Udzha River (Table 1) support our conclusion. Unfortunately, these data were not properly presented and only the mean direction is currently known [14]. Nevertheless, there is good agreement with our data and the independent data of Konstantinov [14]. 
Table 1. Paleomagnetic data from the Udzha paleorift and Anabar shield, northern Siberian Craton.

\begin{tabular}{|c|c|c|c|c|c|c|c|c|c|c|}
\hline \multirow{2}{*}{ Leading Title } & $\mathrm{n} / \mathrm{N}$ & $\operatorname{Dec}\left({ }^{\circ}\right)$ & Inc $\left(^{\circ}\right)$ & $\mathbf{k}$ & $\alpha 95\left(^{\circ}\right)$ & Plat $\left({ }^{\circ} \mathrm{N}\right)$ & Plong $\left({ }^{\circ} \mathrm{E}\right)$ & A95 ( $\left.{ }^{\circ}\right)$ & Coordinates & Ref. \\
\hline & \multicolumn{5}{|c|}{ Average Direction of HT-Component } & \multicolumn{3}{|c|}{ Virtual Geomagnetic Poles } & & \\
\hline Sill at the Udzha and Hapchanyr river junction (2). & $13 / 14$ & 32.4 & -22.8 & 50.3 & 5.9 & -4.4 & 85.3 & 4.6 & $\begin{array}{l}\mathrm{N} 70.81217^{\circ} \\
\mathrm{E} 117.0336^{\circ}\end{array}$ & This study \\
\hline Dyke (3) & $4 / 7$ & 20.5 & -9.2 & 105 & 9 & -13.3 & 95.9 & 6.5 & $\begin{array}{l}\text { N 70.8855 } \\
\text { E } 116.899^{\circ}\end{array}$ & This study \\
\hline Sill of Hapchanyr riv. * & 10 & 32.3 & -22.4 & - & 4.9 & -4.5 & 85.3 & 3.8 & $\mathrm{~N} 71^{\circ}$ E $117^{\circ}$ & [14] \\
\hline Dykes of Kotuy-Olenek complex * & 38 & 33 & -15 & - & 5.7 & -8.3 & 83.9 & 4.2 & $\mathrm{~N} 71^{\circ} \mathrm{E} 118^{\circ}$ & [14] \\
\hline P-T Udzha Traps & 18 & 109.1 & 80.3 & 18.6 & 5.7 & 60.3 & 152.4 & 11.2 & $\begin{array}{l}\mathrm{N} 71.4^{\circ} \\
\mathrm{E} 1153^{\circ}\end{array}$ & [17] \\
\hline Paleomagnetic pole of the Udzha formation & 35 & 237 & 7 & 8 & 9 & -6 & 59 & 6.7 & - & [15] \\
\hline
\end{tabular}

Notes: $\mathrm{n} / \mathrm{N}=$ number of samples in mean direction/ number analyzed; Dec/Inc $=$ declination/inclination of the magnetization vector; $\mathrm{k}, \mathrm{A} 95=$ Fisher's precision parameter [5], radius $\left({ }^{\circ}\right)$ of the $95 \%$ cone of confidence about the mean direction; Plat, Plong = virtual geomagnetic pole latitude, longitude; HT—high-temperature component of magnetization; * sill at the Udzha and Hapchanyr river junction was sampled in different places (sites), the distance between its $\sim 2 \mathrm{~km}$; ${ }^{* *}$ direction, calculated from pole (VGP) coordinates and geographic coordinates $\left(\mathrm{N} 70.82^{\circ} ; \mathrm{E} 117.00^{\circ}\right)$ 
Table 2. Precambrian paleomagnetic poles for Siberian Craton shown in Figure 8.

\begin{tabular}{|c|c|c|c|c|c|c|}
\hline Rock Unit & Code & Age (Ma) & Pole $\left({ }^{\circ} \mathrm{N}\right)$ & Pole $\left({ }^{\circ} \mathrm{E}\right)$ & $\mathrm{A} 95\left(^{\circ}\right)$ & References \\
\hline Nersa compex & Ner & $1641 \pm 8$ & -23 & 130 & 12 & {$[19,21]$} \\
\hline Ilya-Burdur Fm & Il-B & $1690-1500$ & -4 & 120 & 9 & [19] \\
\hline Labaztakh-Kotuykan & $\mathrm{Lb}-\mathrm{Kt}$ & $<$ Il-B & 0 & 94 & 5 & [19] \\
\hline West Anabar Intrusions & WAI & $1503 \pm 2$ & -25 & 61 & 5 & {$[19,22]$} \\
\hline North Anabar Intrusions & NAI & $1483 \pm 17$ & -24 & 75 & 8 & {$[19,22]$} \\
\hline Sololi-Kyutingde & Sl-Kt & $1473 \pm 24$ & -34 & 73 & 10 & {$[23]$} \\
\hline Ungoakhtakh Fm & Ung & ca. 1500 & -23 & 75 & 9 & [15], estimate age from paleomagnetic correlation \\
\hline Udzha Fm & $\mathrm{Ud}$ & $1500-1386$ & -6 & 59 & 7 & [15] \\
\hline Chieress Anabar Dyke & Chrs & $1384 \pm 2$ & -4 & 78 & 7 & [24] \\
\hline Udzha Intrusions & Ud_In & $1386 \pm 30$ & -6 & 87 & 16 & * This study \\
\hline Totta Fm & $\overline{\mathrm{Tt}}$ & $<1100$ & 14 & 85 & 9 & [25] \\
\hline Malgina Fm & $\mathrm{Mlg}$ & $1043 \pm 14$ & 15 & 70 & 3 & {$[28,29]$} \\
\hline Linok Fm & Lnk & $=\mathrm{Mlg}$ & 15 & 76 & 8 & [28], age from correlation \\
\hline Lakhanda Fm & Lhd & $1025-930$ & 2 & 45 & 11 & [18] \\
\hline Derevnya Fm & Der & $=$ Lhd & -5 & 31 & 8 & [18] \\
\hline Kandyk mafic sills & Knd & $942 \pm 19$ & -8 & 19 & 4 & [27] \\
\hline Ust'-Kirba Fm & U-K & $950-930$ & -3 & 25 & 10 & [27] \\
\hline Kitoi mafic intusions & $\mathrm{Kt}$ & 758 & 1 & 22 & 7 & [20] \\
\hline
\end{tabular}

Notes: *-VGP poles; Mlg, Tt, Lhd, Knd, U-K poles have been restored to the Anabar reference frame in pre-Devonian time [30]; Euler parameters from [31]. 


\section{Discussion and Geodynamic Significance}

New U-Pb dating of apatite from the GUD produced an age of $1386 \pm 30 \mathrm{Ma}$, which is indistinguishable from the age of the Chieress dyke (Anabar Shield, $1384 \pm 2$ Ma [24]).

The proximity of the ages of the Anabar and Udzha intrusions is further supported by the similarity of the VGPs obtained from the corresponding magmatic bodies (Figure 7). The geographical positions of these poles are very close (Figure 7 ) and their $95 \%$ confidence circles overlap. The combined data mutually supports each other and supports the occurrence of a large magmatic event which took place in the north of the Siberian platform around 1380 Ma ago.

The obtained age yields new constraints on the timing of sedimentation in the Udzha paleo-rift (Ulahan-Kurung, Ungoakhtah, Khapchanyr and Udzha formations) and indicates the presence of a large $\sim 800$ Ma gap in the Udzha section between $1380 \mathrm{Ma}$ and $\sim 600 \mathrm{Ma}$ (the timing of the deposition of the Ediacarian sediments of the Udzha paleo-rift). Similar large gaps in the sedimentary record were suggested for other regions of the Siberian Craton for time periods ranging from $\sim 1.86 \mathrm{Ga}$ to $800 \mathrm{Ma}$ [32].

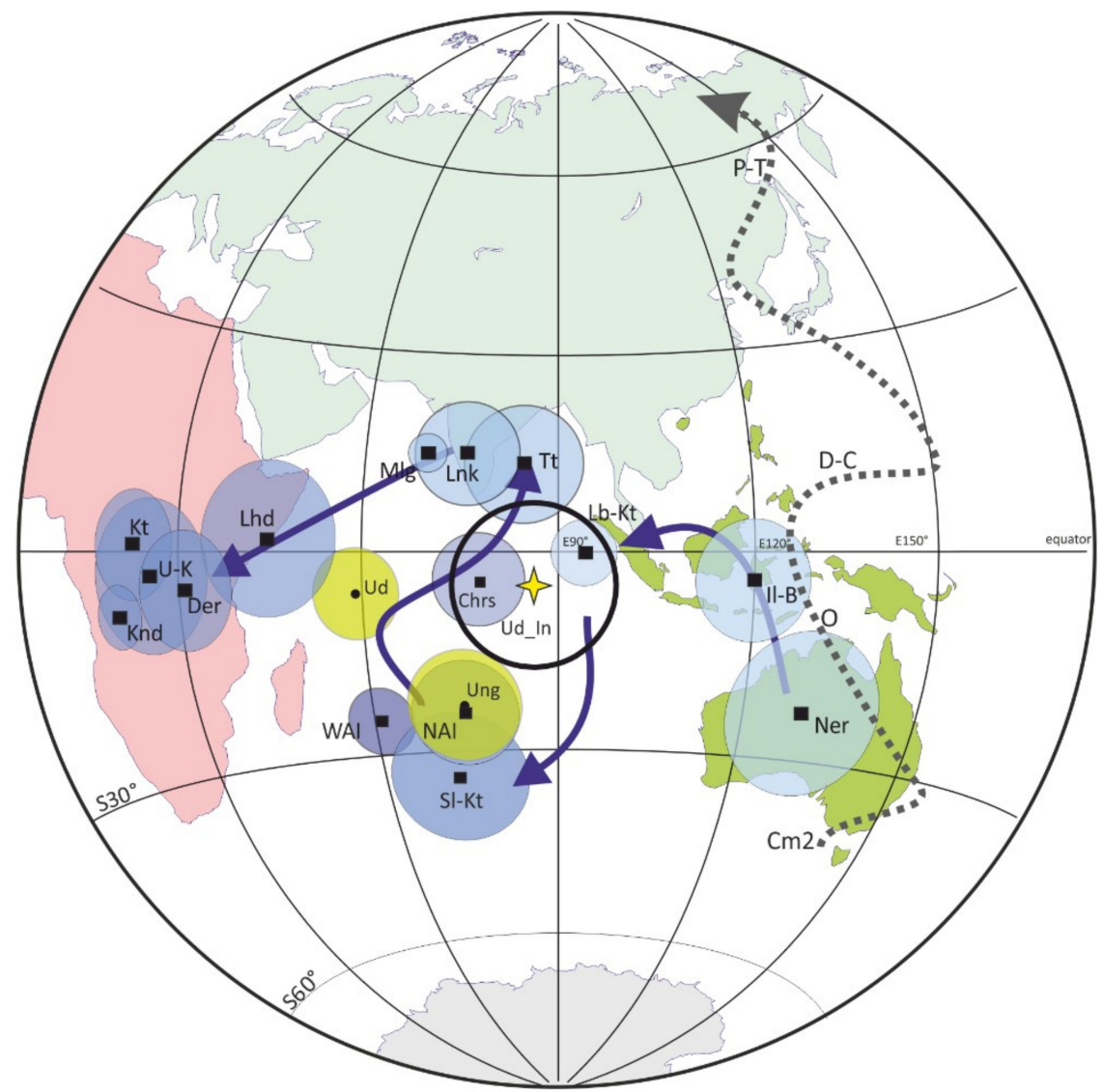

Figure 8. Comparison of the paleomagnetic pole obtained from the mafic intrusions of the Udzha paleo-rift (1386 $\pm 30 \mathrm{Ma}$ ); VGP from the Chieress dyke of the Anabar shield (1384 $\pm 2 \mathrm{Ma}$ [24]) and other Precambrian Siberian poles. Star-VGP for Udzha's intrusions at 1380 Ma. Definitions of the abbreviations are in Table 2. Dotted line shows APWP for Phanerozoic of Siberian craton by [33]; blue arrows - the general trend of Proterozoic Siberian APWP.

The mean VGP based on data from the studied Udzha intrusions and the Chieress dyke (although not completely averaging the geomagnetic secular geomagnetic variations) can nevertheless be used for the preliminary calculation of the Siberian Craton's paleogeographic position (Figure 8). This calculation indicates that 1380 million years ago, the northern (in modern coordinates) regions of the Siberian Craton were located at near-equatorial latitudes, and the craton itself was turned relative to its current position by 140 degrees clockwise (Figure 9). 


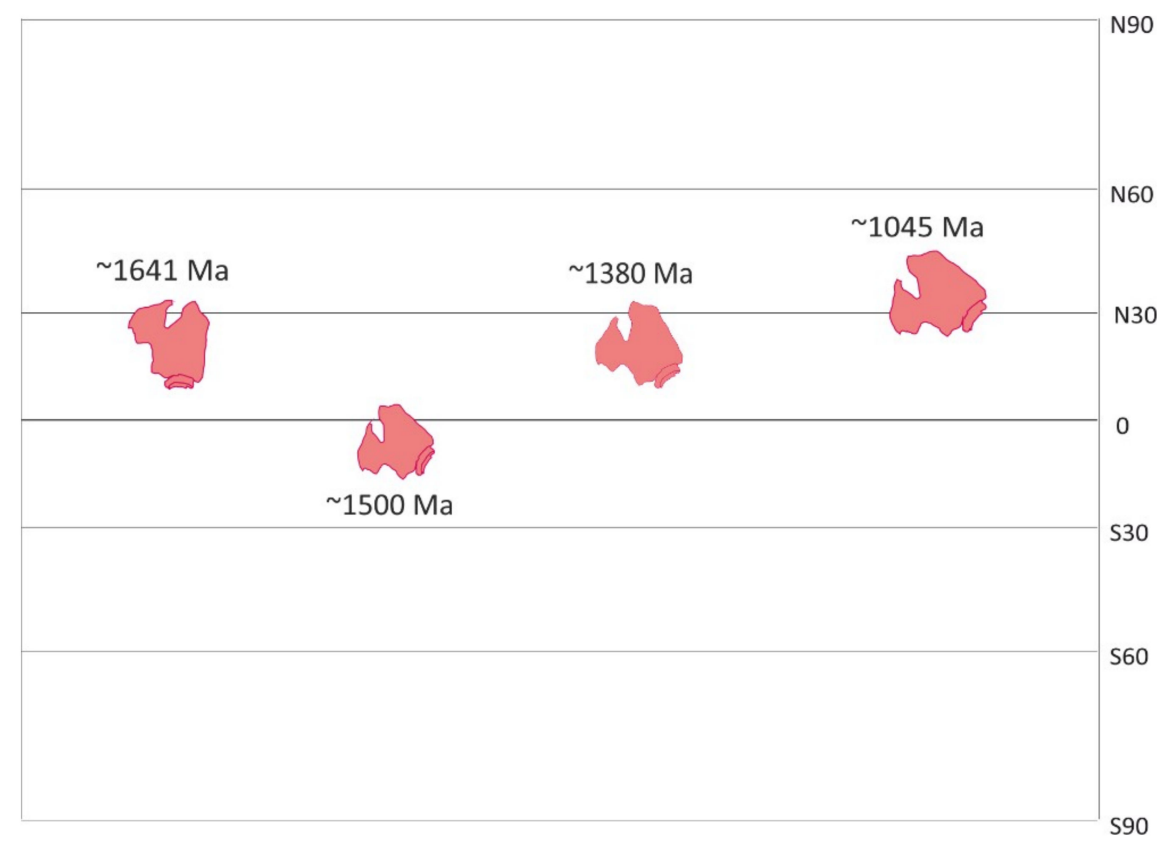

Figure 9. Reconstruction of the latitude position of Siberia $1380 \mathrm{Ma}$ and comparison of latitudinal movement of Siberia in the Mesoproterozoic. For paleomagnetic reconstruction we used the following poles: 1641 Ma [21,22]; 1500 Ma [22]; 1380 Ma (this study); 1043 Ma [26,29].

Supplementary Materials: The following are available online at http:/ /www.mdpi.com/2075-163X/8/12/555/s1, Table S1: manuscript-supplementary.xlsx.

Author Contributions: S.V.M. (Sergey V. Malyshev), A.P. and A.I. conceived and designed this study, conducted the data collation and analysis, and wrote the manuscript. A.P., V.M.S. (Valery M. Savatenkov), S.M., A.A., V.K. and V.D.S. (Vasiliy D. Shcherbakov) performed the experiments, conducted the data collation and analysis. S.V.M. (Sergey V. Malyshev), A.P. and D.G. contributed to revision of the manuscript. A.A. contributed to English spell check. All read and approved the final manuscript.

Funding: The research was supported by the Russian Science Foundation grant (16-17-10068), the grant of the Russian Ministry of Education and Science No.14.Z50.31.0017, the Russian Foundation for Basic Research grant No. 16-05-00642 and the grant of the President of the Russian Federation (MK 739-2017.5). Paleomagnetic research was conducted within the framework of the State Assignment of the IPE RAS, task No.0144-2014-0091.

Conflicts of Interest: The authors declare no conflict of interest.

\section{References}

1. Gladkochub, D.P.; Stanevich, A.M.; Travin, A.V.; Mazukabzov, A.M.; Konstantinov, K.M.; Yudin, D.S.; Kornilova, T.A. The Mesoproterozoic Udzha paleorift (Northern Siberian Craton): New data on age of basites, straigraphy, and microphytology. Dokl. Earth Sci. 2009, 425, 371-377. [CrossRef]

2. Chew, D.M.; Sylvester, P.J.; Tubrett, M.N. U-Pb and Th-Pb dating of apatite by LA-ICPMS. Chem. Geol. 2011, 280, 200-216. [CrossRef]

3. Thompson, J.; Meffre, S.; Maas, R.; Kamenetsky, V.; Kamenetsky, M.; Goemann, K.; Ehrig, K.; Danyushevsky, L. Matrix effects in $\mathrm{Pb} / \mathrm{U}$ measurements during LA-ICP-MS analysis of the mineral apatite. J. Anal. At. Spectrom. 2016, 31, 1206-1215. [CrossRef]

4. Kirschvink, J.L. The least-squares line and plane and the analysis of palaeomagnetic data. Geophys. J. R. Astron. Soc. 1980, 62, 699-718. [CrossRef]

5. Sir Ronald Fisher, F.R.S. Dispersion on a sphere. Proc. R. Soc. Lond. Ser. A Math. Phys. Sci. 1953, 217, $295-305$. [CrossRef]

6. Enkin, R.J. A Computer Program Package for Analysis and Presentation of Paleomagnetic Data; Geological Survey of Canada: Sidney, BC, Canada, 1994; p. 16. 
7. Torsvik, T.H.; Smethurst, M.A. Plate tectonic modelling: Virtual reality with GMAP. Comput. Geosci. 1999, 25, 395-402. [CrossRef]

8. Day, R.; Fuller, M.; Schmidt, V.A. Hysteresis properties of titanomagnetites: Grain-size and compositional dependence. Phys. Earth Planet. Inter. 1977, 13, 260-267. [CrossRef]

9. Dunlop, D.J. Theory and application of the Day plot (Mrs/Ms versus Hcr/Hc) 1. Theoretical curves and tests using titanomagnetite data. J. Geophys. Res. Solid Earth 2002, 107. [CrossRef]

10. Dunlop, D.J. Theory and application of the Day plot (Mrs/Ms versus Hcr/Hc) 2. Theoretical curves and tests using titanomagnetite data. J. Geophys. Res. Solid Earth. 2002, 107. [CrossRef]

11. Butler, R. Paleomagnetism: Magnetic Domains to Geologic Terranes; Blackwell Scientific Publications: Hoboken, NJ, USA, 1992; ISBN 086542070X.

12. McElhinny, M.W.; McFadden, P.L.B.T.-I.G. (Eds.) Chapter Two-Rock Magnetism. In Paleomagnetism; Academic Press: Cambridge, MA, USA, 2000; Volume 73, pp. 31-77. ISBN 0074-6142.

13. Dunlop, D.J.; Özdemir, Ö. Rock Magnetism. Fundamentals and Frontiers; Cambridge University Press (Cambridge Studies in Magnetism): Cambridge, UK, 1997; ISBN 9780511612794.

14. Konstantinov, K.M.; Pavlov, V.E.; Petukhova, E.P. The results of reconnaissance paleomagnetic studies of the rocks of the Udja uplift (north of the Siberian platform). In Paleomagnetism and Magnetism of Rocks; Theory, Practice, Experiment. Workshop Materials Borok 18-21 October 2007; GEOS: Moscow, Russia, 2007; pp. 69-71.

15. Rodionov, V.P. Paleomagnetism of the Upper Precambrian and Lower Paleozoic of the Udja region. In Paleomagnetic Methods in Stratigraphy; VNIGRI: Saint-Peterburg, Russia, 1984; pp. 18-28.

16. McFadden, P.L.; McElhinny, M.W. Classification of the reversal test in palaeomagnetism. Geophys. J. Int. 1990, 103, 725-729. [CrossRef]

17. Veselovskiy, R.V.; Konstantinov, K.M.; Latyshev, A.; Fetisova, A. Paleomagnetism of the trap intrusive bodies in arctic Siberia: Geological and methodical implications. Izv. Phys. Solid Earth 2012, 48, 738-750. [CrossRef]

18. Pavlov, V.E.; Shatsillo, A.; Petrov, P.Y. Paleomagnetism of the upper Riphean deposits in the Turukhansk and Olenek uplifts and Uda Pre-Sayan region and the neoproterozoic drift of the Siberian Platform. Izv. Phys. Solid Earth 2015, 51, 716-747. [CrossRef]

19. Evans, D.A.D.; Veselovsky, R.V.; Petrov, P.Y.; Shatsillo, A.V.; Pavlov, V.E. Paleomagnetism of Mesoproterozoic margins of the Anabar Shield: A hypothesized billion-year partnership of Siberia and northern Laurentia. Precambrian Res. 2016, 281, 639-655. [CrossRef]

20. Pisarevsky, S.A.; Gladkochub, D.P.; Konstantinov, K.M.; Mazukabzov, A.M.; Stanevich, A.M.; Murphy, J.B.; Tait, J.A.; Donskaya, T.V.; Konstantinov, I.K. Paleomagnetism of Cryogenian Kitoi mafic dykes in South Siberia: Implications for Neoproterozoic paleogeography. Precambrian Res. 2013, 231, 372-382. [CrossRef]

21. Metelkin, D.; Belonosov, I.V.; Gladkochub, D.P.; Donskaya, T.V.; Mazukabzov, A.M.; Stanevich, A.M. Paleomagnetic directions from Nersa intrusions of the Biryusa terrane, Siberian craton, as a reflection of tectonic events in the Neoproterozoic. Geol. Geofiz. 2005, 46, 398-413.

22. Ernst, R.E.; Hamilton, M.A.; Soderlund, U.; Hanes, J.A.; Gladkochub, D.P.; Okrugin, A.V.; Kolotilina, T.; Mekhonoshin, A.S.; Bleeker, W.; LeCheminant, A.N.; et al. Long-lived connection between southern Siberia and northern Laurentia in the Proterozoic. Nat. Geosci. 2016, 9, 464-469. [CrossRef]

23. Wingate, M.T.D.; Pisarevsky, S.A.; Gladkochub, D.P.; Donskaya, T.V.; Konstantinov, K.M.; Mazukabzov, A.M.; Stanevich, A.M. Geochronology and paleomagnetism of mafic igneous rocks in the Olenek Uplift, northern Siberia: Implications for Mesoproterozoic supercontinents and paleogeography. Precambrian Res. 2009, 170, $256-266$. [CrossRef]

24. Ernst, R.E.; Buchan, K.L.; Hamilton, M.A.; Okrugin, A.V.; Tomshin, M.D. Integrated Paleomagnetism and U-Pb Geochronology of Mafic Dikes of the Eastern Anabar Shield Region, Siberia: Implications for Mesoproterozoic Paleolatitude of Siberia and Comparison with Laurentia. J. Geol. 2000, 108, 381-401. [CrossRef] [PubMed]

25. Pavlov, V.E. Paleomagnetic poles of the Uchur-Maya Riphaean Hypostratotype and the Drift of the Aldan Block (of the Siberian Craton) in the Riphaean. Doklady Rossiyskoy Akademii Nauk 1994, 336, 533-537.

26. Pavlov, V.E.; Gallet, Y.; Shatsillo, A.V. Paleomagnetism of the Upper Riphean Lakhandinskaya Group in the Uchuro-Maiskii area and the hypothesis of the Late Proterozoic supercontinent. Izv. Phys. Solid Earth 2000, 36, 638-648. 
27. Pavlov, V.E.; Gallet, Y.; Petrov, P.Y.; Zhuravlev, D.Z.; Shatsillo, A. V The Ui Group and Late Riphean Sills in the Uchur-Maya Area: Isotope and Paleomagnetic Data and the Problem of the Rodinia Supercontinent. Geotectonics 2002, 36, 278-292.

28. Gallet, Y.; Pavlov, V.E.; Semikhatov, M.A.; Petrov, P.Y. Late Mesoproterozoic magnetostratigraphic results from Siberia: Paleogeographic implications and magnetic field behavior. J. Geophys. Res. Solid Earth 2000, 105, 16481-16499. [CrossRef]

29. Khudoley, A.K.; Chamberlain, K.R.; Ershova, V.B.; Sears, J.W.; Prokopiev, A.V.; MacLean, J.; Kazakova, G.G.; Malyshev, S.V.; Molchanov, A.; Kullerud, K.; et al. Proterozoic supercontinental restorations: Constraints from provenance studies of Mesoproterozoic to Cambrian clastic rocks, eastern Siberian Craton. Precambrian Res. 2015, 259, 78-94. [CrossRef]

30. Pavlov, V.; Bachtadse, V.; Mikhailov, V. New Middle Cambrian and Middle Ordovician palaeomagnetic data from Siberia: Llandelian magnetostratigraphy and relative rotation between the Aldan and Anabar-Angara blocks. Earth Planet. Sci. Lett. 2008, 276, 229-242. [CrossRef]

31. Evans, D.A.D. The palaeomagnetically viable, long-lived and all-inclusive Rodinia supercontinent reconstruction. Geol. Soc. Lond. Spec. Publ. 2009, 327, 371-404. [CrossRef]

32. Gladkochub, D.P.; Donskaya, T.V.; Wingate, M.T.D.; Mazukabzov, A.M.; Pisarevsky, S.A.; Sklyarov, E.V.; Stanevich, A.M. A one-billion-year gap in the Precambrian history of the southern Siberian Craton and the problem of the Transproterozoic supercontinent. Am. J. Sci. 2010, 310, 812-825. [CrossRef]

33. Cocks, L.R.M.; Torsvik, T.H. Siberia, the wandering northern terrane, and its changing geography through the Palaeozoic. Earth-Sci. Rev. 2007, 82, 29-74. [CrossRef]

(C) 2018 by the authors. Licensee MDPI, Basel, Switzerland. This article is an open access article distributed under the terms and conditions of the Creative Commons Attribution (CC BY) license (http://creativecommons.org/licenses/by/4.0/). 